\title{
Expression of HDAC8 Indicates Poor Prognosis of Esophageal Squamous Cell Carcinoma and Progression to Advanced Stage
}

\author{
Effat Un Nesa ${ }^{1}$, Xuan Chen ${ }^{1}$, Cong Wang ${ }^{1}$, Xue Chen ${ }^{1}$, Yuan Wang ${ }^{2}$, Yan Qu ${ }^{1}, S_{i}$ Mi $^{1}$, Shanghai Guan ${ }^{1}$, \\ Tamanna Zahur ${ }^{3}$, Fengxia Xiao ${ }^{1}$, Cheng Yufeng ${ }^{1^{*}}$
}

${ }^{1}$ Department of Radiation Oncology, Qilu Hospital of Shandong University, Jinan, Shandong, 250012, People's Republic of China

${ }^{2}$ Department of Radiation Oncology, Linyi People's Hospital, Linyi, Shandong, People's Republic of China

${ }^{3}$ Department of Biostatistics, National Institute of Preventive and Social Medicine, People's Republic of Bangladesh

*Corresponding author: Yufeng Cheng, Department of Radiation oncology, Qilu Hospital of Shandong University, Jinan, Shandong, 250012, People's Republic of China, Tel: 86-531-82169831/ Fax: 86-531-86927544; E-mail: qlyufengcheng@126.com

\begin{abstract}
Background: We determined to assess the HDAC8 expression in esophageal squamous cell carcinoma (ESCC) patients and prognostic potential though there is only a little research contribution regarding HDAC8 to tumorigenesis of ESCC.

Methods: The immunohistochemical expression of HDAC8 was investigated on tissue microarrays (TMAs) from 110 patients with esophageal squamous cell carcinoma. The nuclear staining intensity is calculated by the immune reactivity score ranging from (0-12) and divides them into two groups: no expression group and overexpression.

Results: The median follow-up duration was 70 months. Highly regulated HDAC 8 protein significantly predicted decreased 5-year overall survival $(p=0.001)$ and progression-free survival $(p=0.001)$ demonstrated by the log-rank test. Furthermore, HDAC8 protein acts as an independent prognostic factor for overall survival and progression-free survival, which determined after multivariate analyses. By Receiver operating characteristics (ROC) analysis, the value of HDAC8 was $(0.63 \pm 0.54, \mathrm{p}=0.04)$ according to advance cancer stage and $(0.59 \pm 0.06, \mathrm{p}=0.04)$ according to the lymph node status found in the Area under the curve (AUC).

Conclusion: HDAC8 protein is highly regulated in ESCC tissues and potential prognostic indicator for diagnosing patients with decreased survival period.
\end{abstract}

Keywords: Esophageal squamous cell carcinoma; HDAC8; Metastasis; Prognosis; Epigenetics; Lymph node status

\section{Introduction}

Esophageal cancer ranking $6^{\text {th }}$ cause of cancer-related mortality and the $8^{\text {th }}$ most common carcinoma in worldwide ${ }^{[1]}$. The professed Asian belt, that includes Pakistan, Bangladesh, Kazakhstan, Turkey, Northeastern Iran, and northern and central China, which has supreme occurrences of esophageal squamous cell carcinoma among other types of esophageal cancer. Yearly there are more than 100 new cases per 100,000 in this population, and the rate of occurrences is approximately equal in men and women ${ }^{[2]}$. In China, it is the 6th most common cancer and its clinicopathological features quite different from the west ${ }^{[3,4]}$. In the USA, 12,290 new esophageal cancer cases were diagnosed and 15,850 deaths were estimated in $2018^{[5]}$. Though the recent advancement of new diagnostic technique and treatment intervention poor prognosis observes, the 5-year overall survival rate of ESCC patients ranging from $15 \%$ to $25 \%{ }^{[6]}$. Consequently, there is an exigent need to isolate unique biomarkers that will postulate enhance prospects and individualization of treatment protocols.
Received date: April 3, 2019

Accepted date: June 21, 2019

Published date: June 27, 2019

Citation: Cheng, Y., et al. Expression of HDAC8 indicates poor prognosis of esophageal squamous cell carcinoma and progression to advanced stage. (2019) Intl J Cancer Oncol 6(1): 19-25.

Copyright: (C) 2019 Cheng, Y. This is an Open access article distributed under the terms of Creative Commons Attribution 4.0 International License. 
Citation: Cheng, Y., et al. Expression of HDAC8 indicates poor prognosis of esophageal squamous cell carcinoma and progression to advanced stage. (2019) Intl J Cancer Oncol 6(1): 19-25.

During past years, many studies about epigenetic alteration with amendments of histone acetylation status in the development of human carcinoma have published ${ }^{[7,8]}$. An augmented cell proliferation, cell migration, angiogenesis, and invasion by diminishing the transcription of tumor suppressor gene, which is due to increase deacetylation of histones ${ }^{[9]}$. Till now, eighteen different varieties of HDACs (Histone deacetylases) are categorized into four subclasses. By regard to carcinogenesis, class 1 HDACs (HDAC1, 2,3, and 8) determined to be the most important ones. Class 1 HDACs are expressed in the nucleus of normal cells and shows, in divergent to the other classes, a ubiquitous expression $^{[10,11]}$. In the last years, the expression of HDACs and its prognostic value has been analyzed in different kinds of human cancers $^{[12-14]}$. The prognostic role of class 1 HDACs seems to be different in various kinds of tumor entities ${ }^{[11]}$.

HDAC8 is up-regulated in a variety of tissues and localized in the nucleus that is homologous to $\operatorname{Rpd} 3$ in yeast ${ }^{[15]}$, and also sometimes found in cytoplasm ${ }^{[16]}$. In addition, the HDAC8 gene has resided on the X chromosome at the q13 position that is nearer to XIST gene and chromosomal breakpoint ${ }^{[17]}$. It is structurally well-defined enzyme, which also deacetylatesnon-histone proteins. HDAC8 plays an important role as "epigenetic player" in tumorigenesis that allied to deregulation of expression or interaction with transcription factors ${ }^{[18]}$. For that reason, HDAC8 is expressed in many adult carcinoma tissues, such as breast, gastrointestinal tract, lung, prostate, cervical cancer cells, and high regulation of HDAC8 promotes proliferation and reduce apoptosis in hepatocellular cancer ${ }^{[19,20]}$.

The objective of our study is to analyze the expression profile of HDAC 8 by using Immunohistochemistry (IHC) methods on the Tissue Microarrays (TMSs) and correlated them with relevant clinical parameters, mostly related with tumor stage, lymph node status, and tumor differentiation. Furthermore, we also examine the prognostic impact of the expression of HDAC8.

\section{Materials and Methods}

\section{Patient recruitment and data accumulation}

We collected esophageal squamous cell carcinoma tissue samples from 135 patients who underwent subtotal esophagectomy and esophagogastric anastomosis plus regional lymph node dissection done in Qilu hospital in the year of 2010 \& 2011. But we included only 110 -study population in our study due to 25 patients were lost to follow up. Pathologically all cases were confirmed diagnose as ESCC. The patients didn't receive any chemotherapy or radiotherapy before surgical intervention. We also gathered relevant data of the patients from clinical and pathological records, such as age, sex, smoking and drinking habits, histological grade, invasion depth (T stage), lymph node metastasis (N stage), distant metastasis (M stage), degree of differentiation and number of dissected lymph nodes. The TNM classification was performed according to the American Joint Committee on Cancer staging manual ( $7^{\text {th }}$ edition, 2010). The study design and tissue specimen acquisition was performed in accordance with our institutional guidelines, which was approved by ethics boards of Qilu Hospital affiliated to Shandong University. The written informed consent was obtained from all the patients.

Overall survival (OS) is the primary endpoint of our study, which calculated as the time from the date of surgery to death or last follow-up. As a secondary endpoint, we include progression-free survival (PFS), which calculated as the time from surgery to any progression or recurrence.

\section{Immunohistochemistry (IHC)}

During surgery, all fresh specimens were collected and fixed with $10 \%$ formalin that embedded in paraffin. The FFPE cancerous tissues from 2010 \& 2011 were collected from the Department of the pathology of Qilu hospital. All these tissues were cut as $4-\mathrm{mm}$ serial sections. The sections were retrieved with $10 \mathrm{mM}$ citrate buffer followed by de-paraffinization with Xylene and rehydration. For block the endogenous peroxidase enzyme activity we incubate the tissues in $3 \% \mathrm{H}_{2} \mathrm{O}_{2}$ by methanol till 20 minutes at room temperature. Then all the slides again incubated with primary anti-HDAC8 polyclonal antibody ab217702 (1:150, Abcam, Cambridge, MA, USA) overnight in a high humidity chamber at $4^{\circ} \mathrm{C}$. Next day, incubate the slides for 30 minutes at $37^{\circ} \mathrm{C}$ with biotinylated secondary antibodies and streptavidin-peroxidase complex. In the end, by 3,3'-diaminobenzidine solution the slides were counterstained with hematoxylin and fixed with natural balsam. Aimed to negative controls, sections were incubated with PBS instead of primary antibodies.

\section{Assessment of IHC procedure}

After dry off the slides, the segments were examined under a light microscope. Scoring independently done by three investigators. Conflicting scores resolved by determining the consistent values within two investigators as well as the average of the scores. We use the "Immunoreactive score" (IRS) system for determine the staining intensity, that scored as; $0=$ no staining, $1=$ weak staining, $2=$ moderate staining, and $3=$ strong staining. The final score was determined by the multiplying the staining intensity by the percentage of positive cells. Positive cells we determined the scored as; $0=0-10 \%$ positive cells, $1=10-25 \%$ positive cells, $2=26-50 \%$ positive cells, $3=51-75 \%$ positive cells, $4=76-100 \%$ positive cells. The ultimate score was the sum of the staining intensity and the percentage of positive cells, and it was further graded as negative $(-)$, weak $(+)$, moderate $(++)$, strong $(+++)$ respectively $(0-1),(2-3),(4-5),(6-7)$. Depend on the expression of HDAC8 we divided our study population into two groups, non-overexpressed group (- or + ) and overexpressed group $(++$ or +++$)$.

\section{Statistical analysis}

Our all analysis was performed by SPSS v23.0 (SPSS Inc.Chicago,IL). To assess the correlation between HDAC8 expression and biological \& clinical parameters we perform $\mathrm{x}^{2} \&$ Fisher's exact test. Using the chi-square test to determine the significance of the relationship between expression of HDAC8 \& clinicopathological parameters, Univariate analysis was performed. Kaplan-Meier estimates and the log-rank test were performed for survival analysis, to determine overall survival and progression-free survival. For multivariate analysis, we performed cox's proportional hazards regression analysis to test independence from the standard prognostic factor of ESCC. All tests are two-sided and $\mathrm{P}$ values $<0.5$ were considered statistically significant. 


\section{Results}

\section{Staining pattern}

Histone deacetylase 8-protein expression in esophageal squamous cell carcinoma tissues was examined in our study by IHC (immunohistochemical) analysis technique of tissue microarray of 110 patients' tissue samples. The whole study population was evaluated for HDAC8 immunostaining. And it showed high expression levels in 60 to $70 \%$ of ESCC tissues. Within all of our samples, $82.72 \%$ of cases showed high (IRS 9-12) protein expression, and $17.27 \%$ cases showed low (IRS 0-4) protein expression.

\section{Clinical and pathological characteristics}

The baseline features of the 110 patients are summarized in table 1 . The median age of the patients was 65 years; ranging from 25-86 years at the time of diagnoses of ESCC. 70 months (range;1-120 months) was the median follow-up duration. Tumors were classified as pT1 (12 cases, $10.9 \%)$ or pT2 (42 cases, $38.2 \%$ ), and as pT3 (35 cases, $31.8 \%$ ) and remaining tumors classified as pT4 (21 cases, 19.1\%). Lymph node staging categorizing as no positive lymph node, stage 1, stage 2 , stage 3 respectively the cases are 44 cases $(40 \%), 24$ cases $(21.8 \%), 29$ cases $(26.4 \%)$ and 13 cases $(11.8 \%)$. there is also the degree of differentiation of ESCC divide as poor differentiation (47 cases, 42.7\%), moderate differentiation (31 cases, $28.2 \%$ ) and high differentiation (32 cases, 29.1\%).

\section{Correlation of HDAC8 with baseline characteristics}

We observed a significant correlation in between HDAC with the clinicopathological features of our study groups that examined by bilateral $\mathrm{X}^{2}$ test. HDAC8 highly regulated in 10 out of 12 cases $(83.3 \%)$ in stage $\mathrm{T} 1$, and 36 out of 42 cases $(85.7 \%)$, 28 out of 35 cases $(80 \%), 17$ out of 21 cases $(81 \%)$ in stage T2, stage T3 and stage T4 respectively out of 32 poorly differentiated cases, $30(93.8 \%)$ cases were up-regulated, and 23 out of 31 cases $(74.2 \%) \& 30$ out of 32 cases $(93.8 \%)$ respectively for moderate \& well-differentiated.

\section{Correlation between HDAC8 and survival}

The samples of our study groups that were delivered with formalin-fixed paraffin-embedded (FFPE) cancer tissues, within 110 patients 36 patients $(32.7 \%)$ were survived more than 5 years after subtotal esophagectomy and 74 (67.27\%) dies during the follow-up period. The median survival time for all patients was 42 month (average 6-78 month). HDAC8 overexpressed in 102 patients $(92.72 \%)$ patients, though no significant relationship was identified with some of the clinicopathological features such as age, gender, smoking, drinking habit, T stage, $\mathrm{N}$ stage or differentiation (fig 1, table 1). Kaplan-Meier analyses using the log-rank test were performed to calculate the effect of these clinicopathologic factors on the overall survival (OS) and progression-free survival (PFS) rates. The log-rank analysis demonstrated that high HDAC8 expression significantly predicted decreased 5-year OS $(27.5 \%, \mathrm{p}=0.001)$ and PFS $(31.4 \%, \mathrm{p}$ $=0.002)$ (fig2 table2). Furthermore, multivariate analysis identified HDAC8 overexpression as an independent prognostic factor for $\mathrm{OS}(\mathrm{HR}=1.137 \& 95 \% \mathrm{CI}=0.464-2.787, \mathrm{p}=0.001)$ as well as PFS $(\mathrm{HR}=1.48,95 \% \mathrm{CI}=0.627-2.492, \mathrm{p}=0.003)$ (Table 3$)$.
We also conducted receiver operating characteristic (ROC) analysis, and the area under curve (AUC) value of HDAC8 was ( $\mathrm{AUC}=0.63 \pm 0.54, \mathrm{p}=0.04$ ) according to the advanced disease stage and ( $\mathrm{AUC}=0.59 \pm 0.06, \mathrm{p}=0.04$ ) according to the positive lymph node status. (Fig3).

Table 1: The correlation of ESCC Clinicopathologic characteristics of 110 patients' According to HDAC8 expression in FFPE cancerous tissues

\begin{tabular}{|c|c|c|c|}
\hline \multirow{2}{*}{ Baseline Characteristics } & \multicolumn{2}{|c|}{ HDAC8 Overexpression } & \multirow{2}{*}{$\mathrm{p}$ value } \\
\hline & No $(n=19)$ & Yes $(n=91)$ & \\
\hline \multicolumn{4}{|l|}{ Age } \\
\hline $\begin{array}{l}<65 \text { years } \\
>65 \text { years }\end{array}$ & $\begin{array}{c}6(12.2 \%) \\
13(21.3 \%)\end{array}$ & $\begin{array}{l}43(87.8 \%) \\
48(78.7 \%)\end{array}$ & 0.16 \\
\hline \multicolumn{4}{|l|}{ Gender } \\
\hline $\begin{array}{l}\text { Female } \\
\text { Male }\end{array}$ & $\begin{array}{c}8(20.0 \%) \\
11(15.7 \%)\end{array}$ & $\begin{array}{l}32(80.0 \%) \\
59(84.3 \%)\end{array}$ & 0.37 \\
\hline \multicolumn{4}{|l|}{ Smoking } \\
\hline $\begin{array}{l}\text { No } \\
\text { Yes }\end{array}$ & $\begin{array}{c}10(21.7 \%) \\
9(14.1 \%)\end{array}$ & $\begin{array}{l}36(78.3 \%) \\
55(85.9 \%)\end{array}$ & 0.31 \\
\hline \multicolumn{4}{|l|}{ Drinking } \\
\hline $\begin{array}{l}\text { No } \\
\text { Yes }\end{array}$ & $\begin{array}{c}12(22.2 \%) \\
7(12.5 \%)\end{array}$ & $\begin{array}{l}42(77.8 \%) \\
49(87.5 \%)\end{array}$ & 0.21 \\
\hline \multicolumn{4}{|l|}{ Differentiation } \\
\hline $\begin{array}{l}\text { Well } \\
\text { Moderate } \\
\text { Poor }\end{array}$ & $\begin{array}{c}2(6.3 \%) \\
8(25.8 \%) \\
9(19.1 \%)\end{array}$ & $\begin{array}{l}30(93.8 \%) \\
23(74.2 \%) \\
38(80.9 \%)\end{array}$ & 0.08 \\
\hline \multicolumn{4}{|l|}{ T stage } \\
\hline $\begin{array}{l}\mathrm{T} 1 \\
\mathrm{~T} 2 \\
\mathrm{~T} 3 \\
\mathrm{~T} 4\end{array}$ & $\begin{array}{l}2(16.7 \%) \\
6(14.3 \%) \\
7(20.0 \%) \\
4(19.0 \%)\end{array}$ & $\begin{array}{l}10(83.3 \%) \\
36(85.7 \%) \\
28(80.0 \%) \\
17(81.0 \%)\end{array}$ & 0.92 \\
\hline \multicolumn{4}{|l|}{ N stage } \\
\hline $\begin{array}{l}\text { N0 } \\
\text { N1 } \\
\text { N2 } \\
\text { N3 }\end{array}$ & $\begin{array}{l}8(18.2 \%) \\
3(12.5 \%) \\
4(13.8 \%) \\
4(30.8 \%)\end{array}$ & $\begin{array}{c}36(81.8 \%) \\
21(87.5 \%) \\
25(86.2 \%) \\
9(69.2 \%)\end{array}$ & 0.81 \\
\hline \multicolumn{4}{|l|}{ TNM stage } \\
\hline $\begin{array}{l}\text { I } \\
\text { II } \\
\text { III }\end{array}$ & $\begin{array}{l}4(17.4 \%) \\
6(18.2 \%) \\
9(16.7 \%)\end{array}$ & $\begin{array}{l}19(82.6 \%) \\
27(81.8 \%) \\
45(83.3 \%)\end{array}$ & 0.98 \\
\hline
\end{tabular}

$p$ : Chi-square test. Abbreviation: FFPE: Formalin-Fixed Paraffin-Embedded 
Citation: Cheng, Y., et al. Expression of HDAC8 indicates poor prognosis of esophageal squamous cell carcinoma and progression to advanced stage. (2019) Intl J Cancer Oncol 6(1): 19-25.
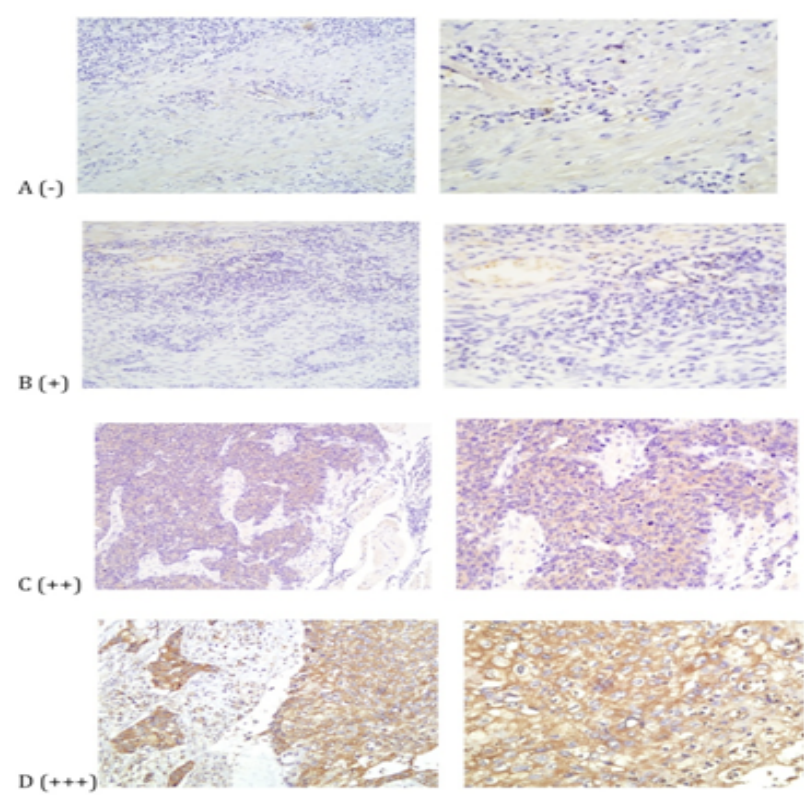

$\times 400$

Figure 1: Immunohistochemical staining of HDAC8 in ESCC tissues, which were graded as $(-),(+),(++)$, or $(+++)(100 *$ and $200 *$, resp.). HDAC8 expression was primarily localized to the cytoplasm of cancer cells.

Table 2: Univariate analysis of prognostic variables of 110 ESCC patients

\begin{tabular}{|l|l|l|}
\hline Variable & 5-year OS & 5-year PFS \\
\hline & p value & p value \\
\hline Age $(<65$ vs. $>65)$ & 0.776 & 0.751 \\
\hline Gender(Male vs.Female) & 0.062 & 0.061 \\
\hline Smoking (Yes vs. No) & 0.628 & 0.503 \\
\hline Drinking (Yes vs. No) & 0.144 & 0.104 \\
\hline T stage (T3\&T4 vs.T1\&T2) & $0.001^{*}$ & $0.001^{*}$ \\
\hline N stage (N2\&N3 vs.N0\&N1) & $0.001^{*}$ & $0.001^{*}$ \\
\hline TNM stage & $0.001^{*}$ & $0.001^{*}$ \\
\hline Differentiation (well vs.moderate \& poor) & 0.381 & 0.56 \\
\hline $\begin{array}{l}\text { HDAC8 (overexpression vs. non-expres- } \\
\text { sion) }\end{array}$ & $0.001^{*}$ & $0.002^{*}$ \\
\hline
\end{tabular}

*And bold values indicate statistically significant $\mathrm{p}$ value. Abbreviation: OS, overall survival; PFS, progression free survival; CI, confidence interval

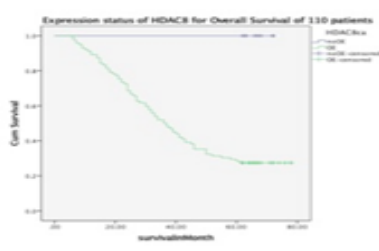

Figure 2A

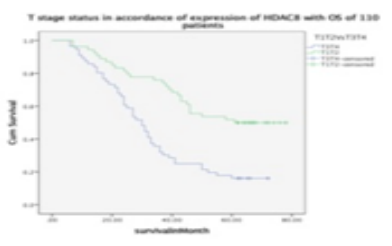

Figure 2C

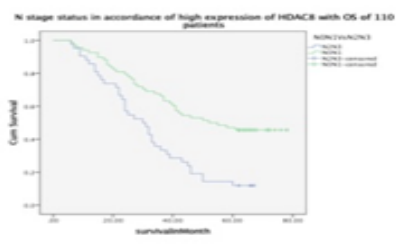

Figure 2E

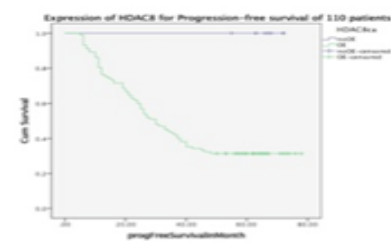

Figure 2B

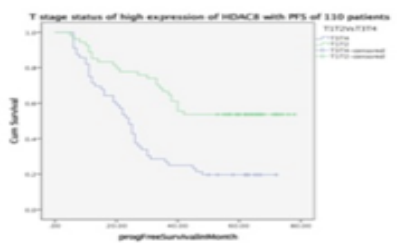

Figure 2D

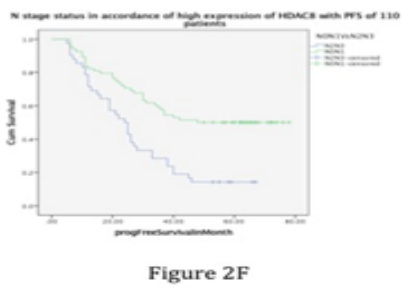

Figure 2:

(A) Kaplan-Meier analysis and log-rank test of HDAC8 for OS of 110 patients. High HDAC8 protein expression significantly predicted decreased OS.

(B) Kaplan-Meier analysis and log-rank test of HDAC8 for PFS. High HDAC8 protein expression was significantly associated with decreased PFS.

(C) Kaplan-Meier analysis and log-rank test of T stage, in accordance of high expression of HDAC8 with OS. Stage T3, T4 shows poor OS with high expression of HDAC8 in compare with stage T1, T2.

(D) Kaplan-Meier analysis and log-rank test of T stage, in accordance of high expression of HDAC8 with PFS. Stage T3, T4 shows poor PFS with high expression of HDAC8 in compare with stage T1, T2.

(E) Kaplan-Meier analysis and log-rank test of $\mathrm{N}$ stage, in accordance of high expression of HDAC8 with OS. Stage N2, N3 shows poor OS with high expression of HDAC8 in compare with stage N0, N1.

(F) Kaplan-Meier analysis and log-rank test of $\mathrm{N}$ stage, in accordance of high expression of HDAC8 with PFS. Stage N2, N3 shows poor PFS with high expression of HDAC8 in compare with stage N0, N1. Abbreviations: OS: overall survival; PFS: progression free survival.

Table 3: Multivariate analysis of independent prognostic factors of 110 ESCC patients by Cox Regression method

\begin{tabular}{|l|c|c|c|c|c|c|}
\hline Variables & \multicolumn{3}{|c|}{ 5-year OS } & \multicolumn{3}{c|}{ 5-year PFS } \\
\hline & HR & $95 \%$ CI & p-value & HR & $95 \%$ CI & p-value \\
\hline T stage & 0.812 & $0.388-1.700$ & 0.58 & 1.278 & $0.398-1.716$ & 0.2 \\
\hline N stage & 0.694 & $0.302-1.594$ & $0.057^{*}$ & 1.062 & $0.435-2.327$ & 0.728 \\
\hline TNM stage & 1.663 & $0.638-4.338$ & 0.298 & 0.937 & $0.557-3.983$ & 0.068 \\
\hline Differentiation & 0.79 & $0.505-1.237$ & $0.006^{*}$ & 0.989 & $0.615-1.424$ & $0.005^{*}$ \\
\hline HDAC8 & 1.137 & $0.464-2.787$ & $0.001^{*}$ & 1.48 & $0.627-2.492$ & $0.003 *$ \\
\hline
\end{tabular}

*And bold p values indicate statistically significant values. Abbreviation: OS, overall survival; PFS, progression free survival; HR, hazard ratio; CI, confidence interval 
$3 \mathrm{~A}$
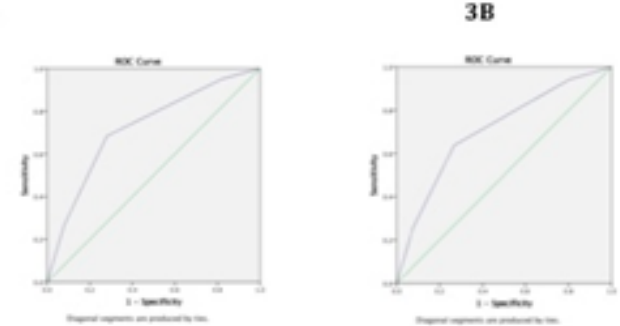

Figure 3: ROC curve for HDAC8 according to advance cancer stage (A) and positive lymph node status (B) predictions. The AUC value was $0.63 \pm 0.54,(\mathrm{p}=0.04)$ according to the advance disease stage prediction and $0.59 \pm 0.06,(\mathrm{p}=0.04)$ according to the positive lymph node status prediction. Abbreviations: OS: overall survival; PFS: progression free survival.

The Univariate analysis also showed, among the examined clinicopathological parameters, traditional prognostic factors including $\mathrm{pT}(\mathrm{p}=0.001)$, nodal status $(\mathrm{p}=0.001)$, and the TNM stage is $(p=0.001)$ statistically significant in association with overall survival (OS). The Univariate analysis also revealed that $\mathrm{pT}$ status $(\mathrm{p}=0.001)$, nodal status $(\mathrm{p}=0.001)$, TNM staging $(p=0.001)$ were also significantly associated with progression-free survival (PFS). We included them in multivariate analysis by Cox regression. In the multivariate analysis for overall survival (OS) we find lymph node status, $\mathrm{p}=0.05$ (HR $=0.694,95 \% \mathrm{CI}=0.302-1.594)$ as well as for progression-free survival (PFS) degree of differentiation, $\mathrm{p}=0.005(\mathrm{HR}=0.989$, $95 \% \mathrm{CI}=0.615-1.424)$.

In multivariate analysis we also come in conclusion that T stage $(p=0.58)$, degree of differentiation $(p=0.006)$ and TNM stage $(p=0.298)$, these three indicators are not statistically significant for OS and T stage $(\mathrm{p}=0.2), \mathrm{N}$ stage $(\mathrm{p}=0.728)$ and TNM stage $(p=0.068)$, these three indicators are not statistically significant for PFS.

\section{Discussion}

In many carcinomas, HDAC8 protein act as one of the culprit biomarker that plays a vital role in DNA deacetylation which is the causative molecular mechanism of tumorigenesis, proliferation, angiogenesis, invasion, progression ultimately regional \& distance metastasis and lymph node involvement ${ }^{[23,24]}$. Furthermore, the up-regulation and oncogenic function of this protein have observed in numerous human carcinoma such as gastrointestinal, lung, breast, colorectal, prostate, hepatocellular, bladder cancer and so on ${ }^{[24-27]}$. In this study, we demonstrated a high-level expression of HDA8 by using immunohistochemistry in esophageal squamous cell carcinoma tissue. We show that HDAC8 expression is an independent prognostic indicator for, overexpression of HDAC8 is responsible for reduced overall survival and progression of the disease. Highly regulated HDAC8 also significantly correlated with positive lymph node status and advanced stage of ESCC.

Last few years many kinds of research are done in adult carcinomas and lymphomas as well as childhood carcinoma such as neuroblastoma ${ }^{[19,20]}$. The level of expression is comparatively higher in cancer tissue than corresponding healthy tissues $^{[22]}$. Inhibition of proliferation of lung, colon, urothelial, and cervical cancer and HDAC8 up-regulation promote prolif- eration and inhibits apoptosis in HCC due to RNA interference (RNAi) that causes knockdown of HDAC8 ${ }^{[28-30]}$. HDAC8 also induce differentiation that evokes to advanced tumor stage and poor outcome ${ }^{[31]}$. Mechanically it has an effect on telomerase activity by preventing human ever-shorter telomerase $1 \mathrm{~B}$ protein against ubiquitin-mediated degradation. And all these functions depend on HDAC8 phosphorylation status ${ }^{[32]}$. In leukemia, abnormal hematopoietic cell proliferation observes, which due to HDAC8 protein associates with the inv ${ }^{[16]}$ fusion protein and other co-repressors to repress acute myeloid leukemia-1 (AML1)- regulated genes such as $\mathrm{p} 21^{[33,34]}$. Moreover, HDAC8 co-expressed in HCC but they directly up-regulated by the lipogenic transcription factor SREBP-1 ${ }^{[35]}$. G.R. Vanaja et al. reported that HDAC8 protein exploits as tubulin deacetylases and highly regulated in cervical carcinoma, that takes part in cancer proliferation and progression ${ }^{[36]}$. Y. Keng et al. demonstrated that in colon cancer HDAC8 overexpression interferes with BMF induction as well as repression of BMF transcription oblige by HDAC8 and STAT3 that further interferes BMF mediated apoptosis ${ }^{[37]}$. Another research showed that significantly up-regulation of HDAC8 in urothelial cancer and HDAC in inhibitors have potential therapeutic effect on outcome ${ }^{[38]}$. Soon young park et al. demonstrated that overexpressed HDAC 8 responsible for breast cancer invasion $^{[39]}$. Another investigation examines that in lung cancer HDAC8 have increased expression, which is by reducing the action of JNK-dependent autophagy ${ }^{[40]}$. Shiyuan Song et al, operating that up-regulation of HDAC8 correlated with advanced gastric cancer stage, due to high proliferation; interfere with apoptosis and cell cycle arrest ${ }^{[41]}$. In our present study, we observe that high expression of HDAC8 that correlated with poor outcome of patients, also responsible for the progression of the disease in the advance stage. This protein also pointedly overexpressed in the patient with lymph node positive ESCC and in an advanced ESCC stage. By monitoring and analyzing all findings it indicates that HDAC8 is a promising indicator of poor prognosis and independently related with survival status of esophageal cancer patients.

Our work has numerous limitations, including its retrospective design and the use of IHC methodology; also it's scoring of staining. We follow a standardized scoring policy in accordance with past works to reduce variability. Besides this study has a few limitations, it can show the way of further research for new therapeutic intervention.

\section{Conclusion}

High expression of HDAC8 is significantly related to poor prognosis of ESCC suffered patients, which also has a meaningful relationship with positive lymph node and advanced disease state. For that reason, overexpressed HDAC8 protein work as a promising biomarker to identify individuals with low survival profile that may have an important role in the diagnosis of the prognostic potential of the disease. To our best knowledge, this is the first report that examining the expression HDAC8 protein expression in ESCC patients and first demonstrating the relationship among advanced disease stage, lymph node status, and the HDAC8 protein.

Acknowledgments: This work was supported by the National 
Citation: Cheng, Y., et al. Expression of HDAC8 indicates poor prognosis of esophageal squamous cell carcinoma and progression to advanced stage. (2019) Intl J Cancer Oncol 6(1): 19-25.

Science Foundation of China (no.81572958 and No.81773228) and the Key Research and Development Program of the Shandong Province (2017GSF18153).

Conflict of interests: The authors declare that they have no conflict of interest.

Informed consent: Informed written consent taken from all patients.

\section{References}

1. Ferlay, J. GLOBOCAN 2008, cancer incidence and mortality worldwide: IARC Cancer Base No. 10; 2010. PubMed | CrossRef $\mid$ Others

2. Pennathur, A., Gibson, M.K., Jobe, B.A. et al. Oesophageal carcinoma. (2013) Lancet 381(9864): 400-412.

PubMed | CrossRef | Others

3. Fitzmaurice, C., Dicker, D., Pain, A., et al. The Global Burden of Cancer 2013. (2015) JAMA Oncol 1(4): 505-527. PubMed | CrossRef|Others

4. Chen, W., Zheng, R., Zeng, H., et al. Annual report on status of cancer in China, 2011. (2015) Chin J Cancer Res 27(1): 2-12.

PubMed | CrossRef | Others

5. Key Statistics for Esophageal Cancer. Am Cancer Society. PubMed |CrossRef $\mid$ Others

6. Pennathur, A., Farkas, A., Krasinskas, A.M., et al. Esophagectomy for T1 esophageal cancer: outcomes in 100 patients and implications for endoscopic therapy. (2009) Ann Thorac Surg 87(4): 1048-1054; discussion 1054-1045. PubMed | CrossRef | Others

7. Yoo, C.B., Jones, P.A. Epigenetic therapy of cancer: past, present and future. (2006) Nat Rev Drug Discov 5(1): 37 50.

PubMed | CrossRef | Others

8. Kristensen, L.S., Nielsen, H.M., Hansen, L.L. Epigenetics and cancer treatment. (2009) Eur J Pharmacol 625(1-3): 131-142.

PubMed | CrossRef | Others

9. Glozak, M.A., Seto, E. Histone deacetylases and cancer. (2007) Oncogene 26(37): 5420-5432. PubMed | CrossRef | Others

10. deRuijter, A.J., van Gennip, A.H., Caron, H.N., et al. Histone deacetylases (HDACs): characterization of the classical HDAC family. (2003) Biochem J 370(Pt 3):737-749. PubMed |CrossRef |Others

11. Weichert, W. HDAC expression and clinical prognosis in human malignancies. (2009) Cancer Lett 280(2): 168-176. PubMed |CrossRef |Others

12. Schneider, G., Krämer, O.H., Schmid, R.M., et al. Acetylation as a transcriptional control mechanism-HDACs and HATs in pancreatic ductal adenocarcinoma. (2011) J Gastrointest Cancer 42(2): 85-92. PubMed | CrossRef | Others

13. Sangha, R., Lara, P.N.Jr., Mack, P.C., et al. Beyond antiepidermal growth factor receptors and antiangiogenesis strategies for non-small cell lung cancer: exploring a new frontier. (2009) Curr Opin Oncol 21(2): 116-123.
PubMed | CrossRef | Others

14. Fritzsche, F.R., Weichert, W., Roske, A., et al. Class I Histone deacetylases 1, 2 and 3 are highly expressed in renal cell cancer. (2008) BMC Cancer 8: 381.

PubMed | CrossRef | Others

15. Liu, N., Li, S., Wu, N., et al. Acetylation and deacetylation in cancer stem-like cells. (2017) Oncotarget 8(51): 8931589325.

PubMed | CrossRef | Others

16. Giannini, G., Cabri, W., Fattorusso, C., et al. Histone deacetylase inhibitors in the treatment of cancer: overview and perspectives. (2012) Future Med Chem 4(11): 14391460 .

PubMed | CrossRef | Others

17. Buggy, J.J., Sideris, M.L., Mak, P., et al. Cloning and characterization of a novel human histone deacetylase, HDAC8. (2000) Biochem J 350(1): 199-205.

PubMed | CrossRef | Others

18. Moradzadeh, M., Tabarraei, A., Hamid, R.S. The Role of Histone Deacetylase (HDAC) as a Biomarker in Cancer. (2015) J Mol Biomarkers Diagnosis 5: 240.

PubMed |CrossRef |Others

19. Vannini, A., Volpari, C., Filocamo, G., et al. Crystal structure of a eukaryotic zinc-dependent histone deacetylase, human HDAC8, complexed with a hydroxamic acid inhibitor. (2004) Proc Natl Acad Sci U.S.A 101(42): 15064-15069. PubMed | CrossRef | Others

20. Wu, J., et al. The up-regulation of histone deacetylase 8 promotes proliferation and inhibits apoptosis in hepatocellular carcinoma. (2013) Dig Dis Sci 58(12): 3545-3553. PubMed | CrossRef |Others

21. Nakagawa, M., Oda, Y., Eguchi, T., et al. Expression profile of class I histone-deacetylases in human cancer tissues. (2007) Oncol Rep 18(4): 769-774.

PubMed |CrossRef | Others

22. Oehme, I., Deubzer, H.E., Wegener, D., et al. Histone deacetylase 8 in neuroblastoma tumorigenesis. (2009) Clin Cancer Res 15(1): 91-99.

PubMed | CrossRef | Others

23. Chakrabarti, A., Oehme, I., Witt, O., et al. HDAC8: a multifaceted target for therapeutic interventions. (2015) Trends Pharmacol Sci 36(7): 481-492.

PubMed | CrossRef|Others

24. Weichert, W., Röske, A., Gekeler, V., et al. Association of patterns of class I histone deacetylase expression with patient prognosis in gastric cancer: a retrospective analysis. (2008) Lancet Oncol 9(2): 139-148.

PubMed | CrossRef | Others

25. Weichert, W., Roeske, A., Niesporek, S., et al. Class I histone de- acetylase expression has independent prognostic impact in human colorectal cancer-specific role of class I HDACs in vitro and in vivo. (2008) Clin Cancer Res 14(6): 1669-1677.

PubMed | CrossRef | Others

26. Weichert, W., Röske, A., Gekeler, V., et al. Histone deacetylases 1, 2 and 3 are highly expressed in prostate cancer and HDAC2 expression is asso- ciated with shorter PSA relapse time after radical prostatectomy. (2008) Br J Cancer 98(3): 604-610. 
PubMed |CrossRef| Others

27. Krusche, C.A., Wülfing, P., Kersting, C., et al. Histone deacetylase-1 and -3 protein expression in human breast cancer: a tissue microarray analysis. (2005) Breast Cancer Res Treat 90(1): 15-23. PubMed |CrossRef |Others

28. Wu, J., Du, C., Lv, Z., et al. The Up-Regulation of Histone Deacetylase 8 Promotes Proliferation and Inhibits Apoptosis in Hepatocellular carcinoma. (2013) Dig Dis Sci 58(12): 3545-3553. PubMed | CrossRef | Others

29. Lehmann, M., Hoffmann, M.J., Koch, A., et al. Histone deacetylase 8 is deregulated in urothelial cancer but not a target for efficient treatment. (2014) J Exp Clin Cancer Res 33: 59 PubMed |CrossRef| Others

30. Singh, T., Prasad, R., Katiyar, S.K. Therapeutic intervention of silymarin on the migration of non-small cell lung cancer cells is associated with the axis of multiple molecular targets including class 1 HDACs, ZEB1 expression, and restoration of miR-203 and E-cadherin expression. (2016) Am J Cancer Res 6(6): 1287-1301.

PubMed | CrossRef | Others

31. Witt, O., Deubzer, H.E., Milde, T., et al. HDAC family: what are the cancer relevant targets? (2009) Cancer Lett 277(1): 8-21.

PubMed | CrossRef | Others

32. Lee, H., Sengupta, N., Villagra, A., et al. Histone deacetylase 8 safeguards the human ever-shorter telomeres $1 \mathrm{~B}$ (hEST1B) protein from ubiquitin-mediated degradation. (2006) Mol Cell Biol 26(14): 5259-5269.

PubMed |CrossRef| Others

33. Durst, K.L., Lutterbach, B., Kummalue, T., et al. The inv (16) fusion protein associates with corepressors via a smooth muscle myosin heavy-chain domain. (2003) Mol Cell Biol 23(2): 607-619.

PubMed |CrossRef|Others

34. Lutterbach, B., Hiebert, S.W. Role of the transcription factor AML-1 in acute leukemia and hematopoietic differentiation. (2000) Gene 245(2): 223-235.

PubMed | CrossRef| Others

35. Tian, Y., Vincent, W.S.Wong., Grace, L.H.Wong., et al. Histone deacetylase HDAC8 promotes insulin resistance and -catenin activation in NAFLD-associated hepatocellular carcinoma. (2015) Cancer Res PubMed | CrossRef |Others

36. Vanaja, G.R., Ramulu, H.G., Kalle, A.M. Overexpressed HDAC8 in cervical cancer cells shows functional redundancy of tubulin deacetylation with HDAC6. (2018) Cell Commun Signal 16(1): 20. PubMed | CrossRef| Others

37. Kang, Y., Nian, H., Rajendran, P., et al. HDAC8 and STAT3 repress BMF gene activity in colon cancer cells. (2014) Cell Death Dis 5: e1476.

PubMed |CrossRef| Others

38. Niegisch, G., Knievel, J., Koch, A., et al. Changes in histone deacetylase (HDAC) expression patterns and activity of HDAC inhibitors in urothelial cancer. (2013) Urol Oncol 31(8): 1770-1779.
PubMed | CrossRef | Others

39. Park, S.Y., Jun, J.A., Jeong, K.J., et al. Histone deacetylases 1,6 and 8 are critical for invasion in breast cancer. (2011) Oncol Rep 25(6): 1677-1681.

PubMed|CrossRef|Others

40. Park, J.Y., Juhnn, Y.S. cAMP signaling increases histone deacetylase 8 expression by inhibiting JNK-dependent degradation via autophagy and the proteasome system in H1299 lung cancer cells. (2016) Biochem Biophys Res Commun 470(2): 336-342.

PubMed |CrossRef | Others

41. Song, S., Wang, Y., Xu, P., et al. The inhibition of histone deacetylase 8 suppresses proliferation and inhibits apoptosis in gastric adenocarcinoma. (2015) Intl J Oncol 47(5): 1819-1828.

\section{PubMed | CrossRef | Others}

Submit your manuscript to Ommega Publishers and we will help you at every step:

- We accept pre-submission inquiries

- Our selector tool helps you to find the most relevant journal

- We provide round the clock customer support

- Convenient online submission

- Thorough peer review

- Inclusion in all major indexing services

- Maximum visibility for your research

Submit your manuscript at OMMEga Publishers https://www.ommegaonline.org/submit-manuscript 